\title{
Colloquy
}

\section{THE LONG TURNING: \\ A Palestinian Refugee in Belgium}

\author{
DIANA ALLAN \\ McGill University \\ (iD) https: / / orcid.org/0000-0001-8903-8627
}

"Since childhood I have never felt safety, stability, or security, not onceeven after I married.” Trying to describe what this felt like, Suhaila likened herself to one condemned to stand forever on the ledge of a roof, who may fall or stay alive. "What might happen later? We don't know. What is destiny hiding for us? We also don't know. I always say, 'Ya Rab, My God!’”'

We were seated in a small, sparsely furnished bedsit close to the train station of St. Niklaas, which her two sons had rented three months earlier. A chair served as a makeshift table, the bed as a sofa. Suhaila reflected on the sequence of events that had brought her from a Palestinian refugee camp in Beirut to this quaint Belgian town, once famous for its textile industry. A deceptively ordered account of multiple displacements followed, beginning with the Israeli bombing of Nabatiyya camp in 1974, months after her birth. For Palestinian refugees in Lebanon, decades of war — civil, regional, and internecine - have made the loss of home and its regeneration a way of life; rupture is routine, anticipated, prepared for. While camp life is reflexively associated with stasis and stagnation, dizzying mobility has also been central to the refugee experience, making forced movement both the cause and imagined solution to insecurity. Perilous, "irregular" journeys to Eu- 
rope, in search of resettlement and better lives, form part of a long-established pattern. Suhaila described the arc of her life as a "long turning" (bahuss haali ka anni barmi taweel), likening herself to the Arab al-Rahil Bedouin, "scattered, from place to place, one day here, one day there."

In this piece, I echo Kali Rubaii's (2020) call to consider what it means to be living in never-ending crisis - a theme also explored in Emrah Yıldız's (2020) account of contraband couriers. How is insecurity - acknowledged as the de facto condition of refugee existence - experienced over the course of a life, across generations, or as it moves over borders? What might it mean to live one's entire life - from birth to old age — in a state of insecurity? How might this protracted temporality alter conceptual understandings of the term-no longer a finite stage, but a "form of life" (Fassin, Wilhelm-Solomon, and Segatti 2017)? While the spatial logics of (in)security have been extensively discussed across academic and policy literatures, commentators have paid less attention to its temporality. ${ }^{2}$ Like other sites of entrenched precarity, Palestinian camps complicate the binary logic of insecurity, which presupposes a reversible condition. For five generations of stateless, disenfranchised Palestinians, insecurity is not an aberrative blip in otherwise secure lives, but a constant; it is understood not as a temporary condition, but as an ontology that has produced particular ways of being and knowing. In the introduction to this colloquy, the editors highlight (in)security's spatio-temporal continuities as "an affect that travels and gives way to further affects" (El Dardiry and Hermez 2020, 197-203). Suhaila's account of her quest for security in Belgium brings into focus the way the structures of racialized exclusion now shaping Europe's asylum system refract and intensify the lived experience of migrant insecurity.

Although the distance separating Shatila and St. Niklaas is 4,139 kilometers, Suhaila's journey to Belgium with her husband, Jihad, entailed travel over the considerably longer distance of 24,672 kilometers, through six countries-Turkey, Panama, Ecuador, Colombia, Spain, and France. Smuggled on false documents, the couple journeyed eighteen days, paying $\$ 25,000$ for the trip. Both their sons, now in their twenties, had taken the same route three months earlier, bringing the family's total expenditure close to $\$ 50,000$. While these journeys entail enormous psychic investment, they also constitute an irreducibly material project, involving the dissolution of assets and the amassing of huge debts. During a phone conversation with me a month before they left, Suhaila had itemized all they had sold to cover the smuggler's fees - their furniture, her mother's gold, Jihad's barber shop of twenty years, and everything in it. Then they waited. When the smuggler finally 
produced their travel papers, he gave them less than twenty-four hours' notice. "I stood in my room like a mad woman, unable to think, moving from one side to the other ...." At the airport, Suhaila was told she could carry no more than seven kilos and was forced to leave a bag with clothes and photographs behind. As she recounted this journey to me months later, the abandoned suitcase figured as a synecdoche for all that had been lost, emblematic of another life now beyond reach.

I retraced the last leg of Suhaila's journey to St. Niklaas in April 2018. Looking out the window at the train platforms of the Gare du Nord in Paris, I recalled her terror at the sight of the security dogs and policemen, and her fear that she would be asked to show identification, which had been torn up in Spain. "When I saw the police I felt my heart fall down [qalbi waq'a]," she told me. "My body was beating with the beat of my heart. I felt like I was stealing or committing a crime." While waiting in the Gare du Nord, she and her husband pretended to talk animatedly on their cellphones: she imagined that if they looked purposeful they would not attract attention. When they arrived in Brussels, their sons were there to meet them. Seeing them standing on the platform - a moment she had rehearsed in her mind for months - she resisted the urge to run and embrace them, fearing that the urgency of her movements might betray her. "When I saw my children I felt comforted, but I didn't want to show emotion in case the police suspected we were immigrants." As I recalled these details, painfully recounted between long pauses over the phone several months before, I reflected on the distance separating her experience from my own, an equation of profound inequality, and the insidious "affective infrastructures" (Glück 2019) of surveillance that migrants must navigate. The haunting image of her awkward reunion with her children in Brussels vividly delineates the maniacal reach of state power-imagined here as monitoring all aspects of migrant life, even down to its most intimate gestures.

A week after their arrival, Suhaila was invited to the Ministry of Immigration for the first of several interviews. "We have information from the Spanish authorities that you were traveling with four underage children on November 20th. Where are these children now?" the immigration officer challenged. "What children?! I didn't travel with children." Suhaila denied the charge and described her rising panic. She knew doubt would be cast over her own rendering of events, and sensed the situation's potential insidiousness: “'This is false!' I protested. The officer saw I was upset. 'Ok, we will check this. Sign here.” From a distance, one might put the error down to inconsistencies of information systems, to the bureaucratic arbitrariness of asylum procedure. In the face of it, however, Suhaila was deeply 
shaken. The accusation remained incomprehensible to her and underscored the indeterminacy of legal protections for asylum seekers. "On the train back to St. Niklaas I was talking to myself. I had lost my mind. They think I would kidnap children?" Pausing, she turned to me and asked, "What should I do? Should I kill myself to rest? This is psychological war [harb nafsiyye]. They made me live this war. They made me live it, and I lived it."

$* * *$

Like the asylum seekers Sophia Rainbird (2014, 460) encountered in the United Kingdom, who were "neither the person they once were, nor yet the person they strive to be," Suhaila described the struggle to come to terms with a situation radically different from what she had imagined. She had anticipated bureaucratic uncertainties, not entrenched racism. Her narrative offers a heuristic for understanding how refugees and asylum seekers might experience the disjuncture between the rhetorical adherence to refugee rights, enshrined in the 1951 Convention Relating to the Status of Refugees and its 1967 amendments, and increasingly exclusionary state policies that make it harder for refugees to access legal status and protections. In her account, the line separating secure and insecure states is blurred and inconstant. Institutional discrimination and terror in the face of law enforcement and state bureaucracy complicate the binary of disorder and order, crisis and refuge. Indeed, her experiences illuminate how they are symbiotically connected: as aggressive border policing relies on the perceived criminality of smugglers, supposed terrorists, and "illegal aliens" for its authority, smugglers in turn profit from increasingly restrictive border regimes. The threat of terrorism - for which the Arab-Muslim migrant now constitutes the living synecdoche - is increasingly invoked to justify preemptive regulations that undermine individual rights and structures of accountability. Suhaila's experiences offer a painful reminder of the differential functioning of borders, regimes of mobility, and asylum procedures that sift out global "undesirables" (Agier 2011). They underscore how, for those imagined as a security threat, these increasingly racialized forms of securitization and surveillance produce affects (most often, paralyzing fear) that are deeply and acutely embodied.

If Palestinians from Lebanon seeking asylum in Europe today have a more realistic understanding of what awaits them than they did a decade ago, the presumption remains that life in the West will afford access to basic rights and protections lacking in Lebanon. Suhaila's journey does not chart a linear path from crisis to refuge and resettlement, but rather a spiral or whorl, what she calls the 
"long turning" of her life. Webs of insecurity that follow refugees across borders are woven more thickly on the loom of the asylum regime and are not disentangled (or undone) even by legal recognition. As Georgina Ramsay (2017, 517) argues, "even after, and as a result of being provided with a legal national identity," racialized forms of state power continue to mark and subjugate refugees as "culturally ungovernable." As Suhaila is again denied the rights and entitlements of citizenship, and waits for her case to be decided in a reception hostel in St. Niklaas, "at once [a] citizen-in-waiting and deportee-in-waiting" (Haas 2017, 76), the asylum system reveals itself to be as much a source of insecurity as its remedy (Brekke and Brochmann 2015).

From an early age Palestinians_ — not only refugees, but especially refugeesunderstand that the labor of life involves navigating the indeterminacies and protracted insecurity of statelessness. Like Muhammad, the Algerian "south-south" spy Darryl Li (2020) found languishing in a migrant detention center in Sarajevo, Palestinian refugees constitute the disposable "assets" of a political game over which they have little leverage. Suhaila's experience offers a lens through which to critically scrutinize the normative privileging of the security of states and borders over that of people. Having lived her entire life outside the space of modern citizenship_-initially as a camp refugee in Beirut, now as asylum seeker in Europeshe is alive to the stark limits of legal protections and the widening gap separating a rhetoric of rights from their implementation. Suhaila's account of her journey to Belgium also makes vivid the dehumanizing objectifications of neoliberal statecraft and the extent to which host states are no longer viewed as guarantors of rights and refuge, but as active producers of illegitimacy, insecurity, and indeterminacy in the lives of refugees.

\begin{abstract}
This article considers the duration and meaning of insecurity - as it is experienced over the course of a life and moves over borders - through the narrative of a Palestinian woman from Shatila now seeking asylum in Belgium. Structured around one person's account of the asylum process, it considers what a singular case can reveal about a collective migrant condition, the inconstant line separating secure from insecure states, and the reconstitution of a secure self in conditions of chronic uncertainty. [Palestinian refugee; asylum; narrative]
\end{abstract}

\title{
NOTES
}

1. Pseudonyms are used throughout. 
2. The work of Ilana Feldman (2018) and Georgina Ramsay (2017) represent notable exceptions.

\section{REFERENCES}

Agier, Michel

2011 Managing the Undesirables: Refugee Camps and Humanitarian Government. Cambridge, UK: Polity.

Brekke, Jan-Paul, and Grete Brochmann

2015 "Stuck in Transit: Secondary Migration of Asylum Seekers in Europe, National Differences, and the Dublin Regulation." Journal of Refugee Studies 28, no. 2: 14562. https://doi.org/10.1093/jrs/feu028.

El Dardiry, Giulia, and Sami Hermez

2020 "Critical Security and Anthropology from the Middle East." Cultural Anthropology 35, no. 2: 197-203. https://doi.org/10.14506/ca35.2.01.

Fassin, Didier, Matthew Wilhelm-Solomon, Aurelia Segatti

2017 "Asylum as a Form of Life: The Politics and Experience of Indeterminacy in South Africa." Current Anthropology 58, no. 2: 160-87. https://doi.org/10.1086/691162.

Feldman, Ilana

2018 Life Lived in Relief: Humanitarian Predicaments and Palestinian Refugee Politics. Berkeley: University of California Press.

Glück, Zoltán

2019 "Security Urbanism and the Counterterror State in Kenya." In Spaces of Security: Ethnographies of Securityscapes, Surveillance, and Control, edited by Setha Low and Mark Maguire, 31-56. New York: New York University Press.

Haas, Bridget M.

2017 "Citizens-in-Waiting, Deportees-in-Waiting: Power, Temporality, and Suffering in the U.S. Asylum System.” Ethos 45, no. 1: 75-97. https://doi.org/10.1111/ etho. 12150 .

Li, Darryl

2020 "The Spy Who Came In from the South." Cultural Anthropology 35, no. 2: 231-36. https://doi.org/10.14506/ca35.2.06.

Rainbird, Sophia

2014 "Asserting Existence: Agentive Narratives Arising from the Restraints of Seeking Asylum in East Anglia, Britain.” Ethos 42, no. 4: 460-78. https://doi.org/10.1111/ etho.12064.

Ramsay, Georgina

2017 "Incommensurable Futures and Displaced Lives: Sovereignty as Control over Time." Public Culture 29, no. 3: 515-38. https://doi.org/10.1215/089923633869584.

Rubaii, Kali

2020 “Trust without Confidence: Moving Medicine with Dirty Hands." Cultural Yıldız, Emrah Anthropology 35, no. 2: 211-17. https://doi.org/10.14506/ca35.2.03.

2020 "Nested In(securities): Commodity and Currency Circuits in an Iran under Sanctions." Cultural Anthropology 35, no. 2: 218-24. https://doi.org/10.14506/ ca35.2.04. 